\title{
Photosynthesis of marine macroalgae and seagrasses in globally changing $\mathrm{CO}_{2}$ environments
}

\author{
Sven Beer*, Evamaria Koch** \\ Marine Sciences \& Technology Center, University of Connecticut, Groton, Connecticut 06340, USA
}

\begin{abstract}
Photosynthetic rates of many marine macroalgae are saturated by the present day inorganic carbon ( $\mathrm{Ci}$ ) composition of seawater, while those of seagrasses (or marine angiosperms) are $\mathrm{CO}_{2}-$ limited. In this study we attempted to simulate the Ci conditions of near-shore seawater during the time that seagrasses colonised the sea (in the Cretaceous), and compare the photosynthetic performance of representatives of the 2 plant groups under those versus present day conditions. The results show that the seagrasses have an affinity for $\mathrm{Ci}$ at least as high as the algae under the low $\mathrm{pH}$ and high $\mathrm{CO}_{2} / \mathrm{HCO}_{3}{ }^{-}$concentration ratios simulating near-shore areas of the Cretaceous seas, indicating that their photosynthetic capacity then matched that of macroalgae. However, in the high $\mathrm{pH}$ and high $\mathrm{CO}_{2} / \mathrm{HCO}_{3}^{-}$ratios of today, their affinity for $\mathrm{Ci}$ is lower than that of the macroalgae, and it is suggested that this deficiency renders them a lower ability for $\mathrm{Ci}$ utilisation. This situation may possibly be reversed again as global $\mathrm{CO}_{2}$ levels of the atmosphere and, consequently, of near-shore marine habitats increase in the future
\end{abstract}

KEY WORDS: Marine macroalgae Seagrasses Photosynthesis $\mathrm{CO}_{2}$ Global change

\section{INTRODUCTION}

Two major groups of marine macrophytes exist today, macroalgae (seaweeds) and seagrasses (submerged angiosperms). While the former group has evolved in the oceans from the early times of plantlife existence [from cyanobacteria (ca 3.5 billion years ago), via microalgae (ca 1.3 billion years ago), to the first occurrence of macroalgae (ca 1 billion to 750 million years ago)], fossil evidence dates the earliest seagrasses to the Cretaceous period, only ca 90 million years ago. This plant group originated from terrestrial angiosperms which invaded the seas either directly or via freshwater forms (den Hartog 1970). For these plants, life in the oceans required adaptations to factors such as high salinity (by systems which could

\footnotetext{
- Present and permanent address: Department of Plant Scjences, Tel Aviv University, Tel Aviv 69978, Israel.

E-mail: svenbeer@post.tau.ac.il

- Present address: Horn Point Environmental Laboratories, University of Maryland, PO Box 775, Cambridge, Maryland 21613, USA
}

compartmentalise salts away from metabolically active sites; Beer et al. 1980, Jagels 1983), attenuated light (by having the chloroplasts in the outermost, epidermal cell layer; Tomlinson 1980) and anoxic sediments (by a system of aerial canals, called lacunae, allowing photosynthetically derived $\mathrm{O}_{2}$ to be transported to the roots; Smith et al. 1984). In addition, and concerning the focus of this study, as seagrasses colonised the sea they had to adapt to diffusivity of $\mathrm{CO}_{2}$ in the liquid orders of magnitude lower than in the aerial medium from which they came. However, at the time when seagrasses started to inhabit the oceans the atmospheric, and hence the near-shore seawater equilibrium, $\mathrm{CO}_{2}$ concentration was higher than it is today (Arthur et al. 1991, Berner 1991). This, and the potential advantage of seagrasses in having roots (and thus being able to extract nutrients other than inorganic carbon (Ci) from the sediment] apparently allowed them ta develop into a prolific group of marine macrophytes. Despite their low diversity (there are only some 50 species), seagrasses are the dominant macrophytes of many near-shore softbottom ecosystems, where they comprise an impor- 
tant, highly productive, component of the benthic environment (McRoy \& McMillan 1977) However, present seagrass ecosystems seem to be sensitive to human-induced perturbations, and a decline in seagrass dominated areas has been noted in several regions of the world (Dennison et al. 1993).

Presently, seawater in equilibrium with air contains ca $13 \mu \mathrm{M} \mathrm{CO}$ and $2.2 \mathrm{mM}$ anionic carbon, mainly in the form of $\mathrm{HCO}_{3}{ }^{-}$. Under these conditions, photosynthesis of marine macroalgae is often saturated by the seawater Ci-composition, largely because they can efficiently use $\mathrm{HCO}_{3}^{-}$(Beer 1994). In contrast, seagrasses possess less efficient systems for utilising $\mathrm{HCO}_{3}{ }^{-}$, and their photosynthesis is therefore $\mathrm{Ci}$-limited because of the low concentration and slow diffusive supply of $\mathrm{CO}_{2}$ to the leaves (Beer 1989). During the Cretaceous era, however, the atmospheric $\mathrm{CO}_{2}$ concentration was 3 to 12 times higher than it is today, and the $\mathrm{pH}$ of the seawater has also been estimated to have been lower in the past (Berner et al. 1983, Spivack et al. 1993), causing a proportionally lower Ci fraction to be present as ionic $\mathrm{Ci}$ (see below). Assuming equilibrium between the air and near-shore marine habitats where seagrasses and marine macroalgae grew (and disregarding a slight effect of different temperatures on the solubility of $\mathrm{CO}_{2}$ ), the corresponding concentration of dissolved $\mathrm{CO}_{2}$ was thus 40 to $150 \mu \mathrm{M}$. Therefore, we hypothesised that seagrasses had a better photosynthetic ability during past eras in shallow marine habitats. Accordingly, in this work we explored the effects of the possible differences in the marine $\mathrm{Ci}$ environment of today and that in which seagrasses evolved during the Cretaceous on the photosynthetic yields of 2 common seagrasses and that of some common macroalgae.

\section{MATERIALS AND METHODS}

The seagrasses used in this study were the temperate species Zostera marina (from Avery Point, Connecticut, USA) and the sub-tropical Thalassia testudinum (shipped overnight from St. Petersburg, Florida, USA, courtesy of Dr M. Durako), while the macroalgae consisted of the ubiquitous green species Ulva lactuca and the common temperate red and brown algae Palmaria palmata and Laminaria saccharina, respectively (all collected at Avery Point).

Cut sections ( $3 \mathrm{~cm}$ long) from young leaves of the seagrasses, or $1.2 \mathrm{~cm}$ diameter circular thallus discs of the macroalgae (cut out with a cork borer), were preincubated in normal, air-sparged, seawater at $20^{\circ} \mathrm{C}$ and at an irradiance of $200 \mu \mathrm{mol}$ photons $(400$ to $700 \mathrm{~nm}) \mathrm{m}^{-2} \mathrm{~s}^{-1}$ for at least $1 \mathrm{~h}$ prior to experimentation. Photosynthetic rates were then measured for each leaf section or thallus disc using Hansatech DW $1 \mathrm{O}_{2}$ electrode chambers (set to $2 \mathrm{ml}$ volume) connected to $\mathrm{CB} 1$ $\mathrm{D}$ control units and interfaced with a computer via an IF1/2 interface card (Hansatech, King's Lynn, UK). The temporal resolution of the $\mathrm{O}_{2}$-tracings was $<1 \mathrm{~s}$, and rates were calculated between 227 (air equilibrium) and $300 \mu \mathrm{M} \mathrm{O}_{2}$, no inhibitory $\mathrm{O}_{2}$ response was observed within this range. The temperature and irradiance (saturating for photosynthesis of all species) were kept the same as during the pre-incubation, and the media in the measuring vials were agitated by fast spinning magnetic stir-bars (so as not to limit the $\mathrm{Ci}$ supply to the plant material).

Photosynthetic rates of the various marine macrophytes were first measured in normal seawater (2.1 to $2.2 \mathrm{mM} \mathrm{Ci}$ at $\mathrm{pH} 8.0$ to 8.1 ; the natural seawater used was of slightly lower $\mathrm{pH}$ and total $\mathrm{Ci}$ than that calculated for Table 1). After steady-state photosynthetic rates had been reached (ca 5 and $2 \mathrm{~min}$ for the seagrasses and macroalgae, respectively), Ci was added to the closed system by injecting $\mu \mathrm{l}$ amounts of a $100 \mathrm{mM} \mathrm{NaHCO}$ solution so as to create higher than ambient $\mathrm{Ci}$ levels. In other experiments, a synthetic seawater medium was used instead of natural seawater. This medium consisted of $450 \mathrm{mM} \mathrm{NaCl}, 30 \mathrm{mM}$ $\mathrm{MgSO}_{4}, 10 \mathrm{mM} \mathrm{KCl}$ and $10 \mathrm{mM} \mathrm{CaCl}_{2}$ (Beer \& Eshel 1983), and it was found to be adequate for maintaining steady-state photosynthetic rates (after the addition of $\mathrm{NaHCO}_{3}$ ) for at least $2 \mathrm{~h}$. The $\mathrm{pH}$ was adjusted by injecting $1 \mathrm{M}$ solutions of $\mathrm{N}$-2-hydroxyethylpiperazine- $\mathrm{N}^{\prime}$-2-ethanesulfonic acid (HEPES) for the $\mathrm{pH}$ values 8.2 and 7.0 and $2-\mathrm{N}$-morpholinoethanesulfonic acid (MES) for $\mathrm{pH} 6.0$, yielding final concentrations of $50 \mathrm{mM}$. The plants were left to photosynthesise in the buffered synthetic seawater medium till zero gas exchange had been reached (which could take up to 20 min at $\mathrm{pH}$ 6.0), and $\mu \mathrm{l}$ aliquots of the $\mathrm{NaHCO}_{3}$ solution were then injected so as to create increasing $\mathrm{Ci}$ concentrations. At pH 6.0, 1 low (but saturating) $\mathrm{NaHCO}_{3}$ concentration was injected, and the plants were left to photosynthesise till zero gas exchange had again been reached. The hyperbolic curves of $\mathrm{O}_{2}$ evolution thus created (as $\mathrm{Ci}$ from the synthetic seawater was used up) were utilised in order to determine both Ci contents at each instance (assuming a photosynthetic quotient of 1.0 and a $\mathrm{CO}_{2}$ compensation point close to zero) and photosynthetic rates (calculated as the tangents of the curve at various $\mathrm{Ci}$ concentrations). The rationale and details for such determinations of $\mathrm{Ci}$ responses has been described previously (Beer \& Björk 1994). Concentrations of the various $C_{i}$ forms were calculated using the program CARBON (Beer \& Eshel 1983) for either the solutions in the $\mathrm{O}_{2}$-electrode measuring systems ('closed system' calculations) or for the values in Table 1 ('open system' calculations). 
Table 1. Concentrations of various $\mathrm{C}$ forms in seawater of different $\mathrm{pH}$ values at various $\mathrm{CO}_{2}$ concentrations in the air phase (assuming equilibrium with the air, a salinity of $35 \%$ and a temperature of $20^{\circ} \mathrm{C}$; calculated using program CARBON, Beer \& Eshel 1983)

\begin{tabular}{|c|c|c|c|c|c|c|c|c|c|}
\hline \multirow{2}{*}{$\begin{array}{l}\text { Air } \mathrm{CO}_{2} \text { conc. } \\
(\mathrm{ppm})\end{array}$} & \multicolumn{3}{|c|}{ pH 8.2 (today) } & \multicolumn{3}{|c|}{$\mathrm{pH} 7.0$} & \multicolumn{3}{|c|}{$\mathrm{pH} 6.0$} \\
\hline & $\begin{array}{c}\mathrm{CO}_{2} \\
(\mu \mathrm{M})\end{array}$ & $\begin{array}{c}\mathrm{HCO}_{3}^{-} \\
(\mu \mathrm{M})\end{array}$ & $\begin{array}{l}\mathrm{CO}_{3}^{2-} \\
(\mu M)\end{array}$ & $\begin{array}{c}\mathrm{CO}_{2} \\
(\mu \mathrm{M})\end{array}$ & $\begin{array}{c}\mathrm{HCO}_{3}{ }^{-} \\
(\mu \mathrm{M})\end{array}$ & $\begin{array}{l}\mathrm{CO}_{3}^{2-} \\
(\mu \mathrm{M})\end{array}$ & $\begin{array}{c}\mathrm{CO}_{2} \\
(\mu \mathrm{M})\end{array}$ & $\begin{array}{c}\mathrm{HCO}_{3}- \\
(\mu \mathrm{M})\end{array}$ & $\begin{array}{l}\mathrm{CO}_{3}{ }^{2-} \\
(\mu \mathrm{M})\end{array}$ \\
\hline 340 (today) & 12.5 & 1991 & 363 & 12.5 & 126 & 1.4 & 12.5 & 12.6 & 0.0 \\
\hline $1020(3 \times)$ & 37.5 & 5973 & 1089 & 37.5 & 378 & 4.2 & 37.5 & 37.8 & 0.0 \\
\hline $1700(5 \times)$ & 62.5 & 9955 & 1815 & 62.5 & 630 & 7.0 & 62.5 & 63.0 & 0.0 \\
\hline $2720(8 x)$ & 100 & 15928 & 2904 & 100 & 1008 & 11.2 & 100 & 101 & 0.0 \\
\hline
\end{tabular}

After experimentation, all plant samples were dissolved in $5 \mathrm{ml}$, N-dimethyl formamide overnight, and chlorophyll concentrations were measured spectrophotometrically (Inskeep \& Bloom 1985); all photosynthetic rate values were normalised to a chlorophyll $a+b$ basis.

\section{RESULTS}

Table 1 summarises the expected effects of atmospheric $\mathrm{CO}_{2}$ concentrations and $\mathrm{pH}$ on the dissolved $\mathrm{Ci}$ composition of near-shore seawater during the time that seagrasses evolved in comparison to today. Since the dissolution of $\mathrm{CO}_{2}$ is virtually independent of $\mathrm{pH}$, there is a linear relationship between the increase in aerial and aqueous $\mathrm{CO}_{2}$ concentrations. However, since high $\mathrm{pH}$ is coupled with the presence of ionic $\mathrm{Ci}$, the lower $\mathrm{pH}$ of past periods (Spivack et al. 1993), possibly 1 to $2 \mathrm{pH}$ units lower in the Cretaceous than today (Berner et al. 1983) means that a smaller percentage of the $\mathrm{Ci}$ was in the form of $\mathrm{HCO}_{3}^{-}$and carbonate ions $\left(\mathrm{CO}_{3}{ }^{2-}\right)$ and, thus, that the total $\mathrm{Ci}$ concentration was lower.

The results of the photosynthetic measurements in normal seawater to which $\mathrm{NaHCO}_{3}$ had been added are shown in Fig. 1. Both seagrass species were Ci-limited in ambient seawater (where they photosynthesised only ca $50 \%$ of maximal rates), and photosynthesis was saturated at 5 to $7 \mathrm{mM} \mathrm{Ci}$. On the other hand, the 3 macroalgae were at, or close to, $\mathrm{Ci}$ saturation in normal seawater.

We then measured net photosynthetic rates in synthetic seawater media, buffered to various $\mathrm{pH}$ values, to which $\mathrm{NaHCO}_{3}$ was added so as to form increasing concentrations of $\mathrm{Ci}$. At pH 8.2, both seagrass species showed a significantly lower affinity for $\mathrm{Ci}$ [expressed as higher half-saturation $\left(K_{1 / 2}\right)$ values] than did the algae (Fig. 2), and photosynthetic rates of the latter were saturated (or nearly saturated for Laminaria saccharina) at the present day $\mathrm{Ci}$ level $(1 \times$ in Fig. 2 a). At $\mathrm{pH} 7.0$, the seagrasses had a higher affinity for Ci than

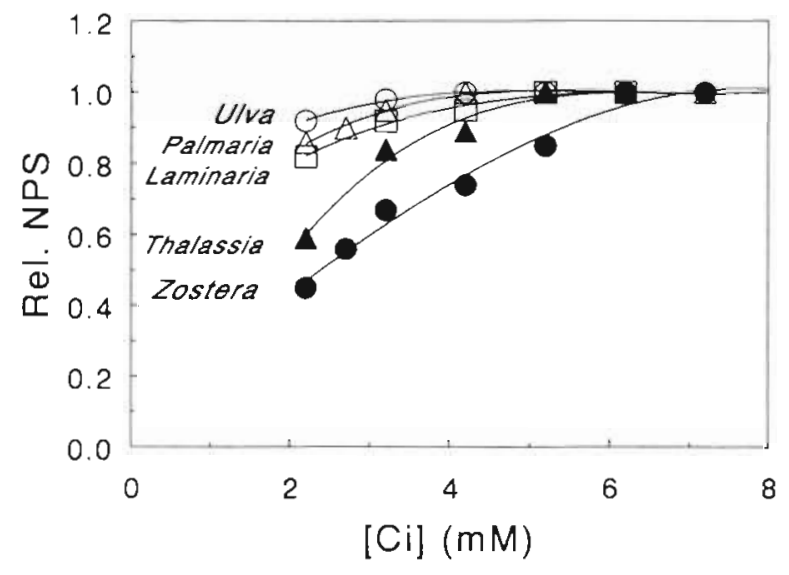

Fig. 1. Net photosynthetic rates (NPS) of 2 seagrasses (solid symbols) and 3 marine macroalgae (open symbols) in natural seawater $(2.2 \mathrm{mM} \mathrm{Ci})$ following additions of $\mathrm{Ci}$. Rates are given relative to the maximal mean rate for each species; the coefficient of variance was less than $10 \%$. Maximal mean rates, $\pm \mathrm{SD}$ ( $\mathrm{n}=9$ to 10 ), of net photosynthesis (in $\mu \mathrm{mol} \mathrm{O}_{2} \mathrm{mg}$ $\mathrm{chl}^{-1} \mathrm{~h}^{-1}$ ) were for Zostera marina $38.3 \pm 5.4$; Thalassia testudinum $25.1 \pm 4.7$; Ulva lactuca $105 \pm 8.9$; Palmaria palmata $91.0 \pm 3.5 ;$ Laminaria saccharina $30.0 \pm 3.1$

2 of the macroalgae, and at $\mathrm{pH} 6.0$ there was no significant difference in affinity for any of the marine plants investigated, and saturation of photosynthesis occurred at ca $0.2 \mathrm{mM} \mathrm{Ci}$.

\section{DISCUSSION}

Our results show that although both the seagrasses and marine macroalgae have a higher affinity for $\mathrm{Ci}$ when a larger part of the carbon pool consists of $\mathrm{CO}_{2}$ (i.e. at lower pH values), the macroalgae are $\mathrm{Ci}$ saturated in the present day $\mathrm{Ci}$ composition of seawater (in which $\mathrm{HCO}_{3}^{-}$is present at a concentration some 160 times that of $\mathrm{CO}_{2}$ ), while the seagrasses are not. This corroborates previous conclusions for the 2 plant groups (Beer 1989), and may be related to the fact that marine macroalgae have evolved for a much longer time in the sea than have the seagrasses and/or that 

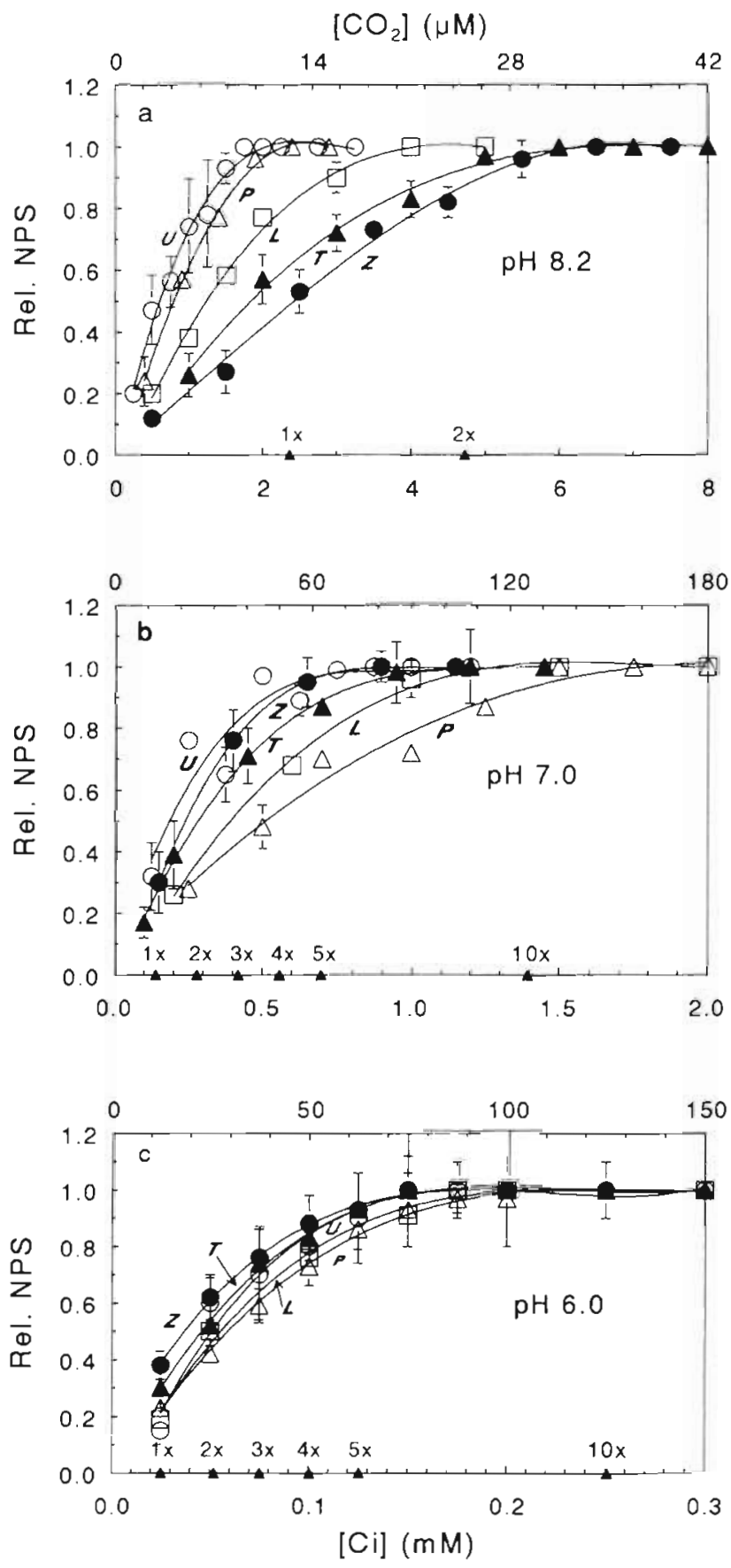

Fig. 2. Net photosynthetic rates (NPS) of 2 seagrasses (solid symbols) and 3 marine macroalgae (open symbols), at 3 different $\mathrm{pH}$ values, in synthetic seawater to which vanous amounts of $\mathrm{Ci}$ were added. Rates are given relative to the maximal mean rate for each species $\pm S D(n=9$ to 10). Maximal average rates of net photosynthesis (in $\mu \mathrm{mol} \mathrm{O} \mathrm{O}_{2} \mathrm{mg} \mathrm{chl}^{-1}$ $\mathrm{h}^{-1}$ ) at $\mathrm{pH} 8.2,7.0$ and 6.0 , respectively, were for Zostera marina $(Z): 21.2 \pm 1.7,28.4 \pm 3.0,21.6 \pm 6.8$. Thalassia testudinum $(T): 18.6 \pm 2.6 ; 21.7 \pm 2.0$ and $17.6 \pm 3.4 ;$ Ulva lactuca (U): $59.4 \pm 10.1,62.0 \pm 21.9$ and $66.9 \pm 3.2$, Palmaria palmata (P): $94.7 \pm 6.2,102.3 \pm 13.2$ and 86.4 \pm 9.2 ; Laminaria saccharina (L): $29.1 \pm 7.6,40.1 \pm 3.0$ and $31.2 \pm 0.4$. Triangles on the $x$-axes designate multiple increases in Ci of today's value $(1 \times)$ several groups of the macroalgae feature a genetic flexibility from which a better $\mathrm{HCO}_{3}$ utilisation system could have developed (Beer 1994). The high photosynthetic capacity of Ulva lactuca (Drechsler et al. 1993) and Palmaria palmata (Kübler \& Raven 1994) is likely due to their efficient $\mathrm{HCO}_{3}{ }^{-}$-utilisation systems, and a trans-membranal $\mathrm{HCO}_{3}{ }^{-}$transporter has been suggested for Ulva sp. (Drechsler et al. 1993). Bicarbonate utilisation by the seagrass Zostera marina is partly driven by external, carbonic anhydrase mediated, $\mathrm{HCO}_{3}{ }^{-}$ dehydration (Rehnberg \& Beer unpubl.), but such a system has been viewed as less efficient than direct $\mathrm{HCO}_{3}{ }^{-}$transport as found in some macroalgae at potentially $\mathrm{CO}_{2}$-limiting conditions (Drechsler et al. 1993, 1994, Axelsson et al. 1995). The recently found ambient $\mathrm{CO}_{2}$ limitation for growth in Zostera marina (Thom 1995) may be due to this apparent disadvantage. On the other hand, it is also shown here that seagrasses can have a higher affinity than some (at $\mathrm{pH}$ 7.0), or the same affinity as (at $\mathrm{pH}$ 6.0), marine macroalgae to $\mathrm{Ci}$ at lower $\mathrm{pH}$ values where increasingly more of the $\mathrm{Ci}$ is present in the form of $\mathrm{CO}_{2}$ rather than $\mathrm{HCO}_{3}{ }^{-}$(the ratio between $\mathrm{CO}_{2}$ and $\mathrm{HCO}_{3}{ }^{-}$is $1: 160$ at $\mathrm{pH} 8.2,1: 10$ at $\mathrm{pH} 7.0$ and $1: 1$ at $\mathrm{pH} 6.0$, see also Table 1).

Based on the present results, it can be argued that since near-shore dissolved- $\mathrm{CO}_{2}$ levels during the Cretaceous were higher (and since the $\mathrm{pH}$ was lower and, consequently, the $\mathrm{CO}_{2} / \mathrm{HCO}_{3}{ }^{-}$ratio was higher), it follows that the $\mathrm{Ci}$ acquisition by seagrasses was likely conducive to a higher productivity per se (as well as relative to that of marine macroalgae) at the time when they colonised the seas than it is now. If we assume that the pH was 6.0, then all tested species would photosynthetically saturate at $0.2 \mathrm{mM} \mathrm{Ci} \mathrm{(Fig.} \mathrm{2c).} \mathrm{Since}$ the $\mathrm{CO}_{2} / \mathrm{HCO}_{3}{ }^{-}$ratio is ca $1: 1$ at that $\mathrm{pH}$, and since a $\mathrm{HCO}_{3}{ }^{-}$concentration of $0.1 \mathrm{mM}$ could not significantly contribute to photosynthesis of any of the tested species (Fig. 2a), it follows that photosynthetic saturation would occur at a seawater $\mathrm{CO}_{2}$ concentration of around $0.1 \mathrm{mM}$, corresponding to an atmospheric $\mathrm{CO}_{2}$ concentration of 8 times the present one. If we assume a pH of 7.0, then the higher affinities for $\mathrm{Ci}$ of the 2 seagrasses than those of 2 of the macroalgae (Fig. 2b) indicate that they would have had an absolute advantage in $\mathrm{Ci}$ acquisition over these 2 macroalgae, and their photosynthetic potential would equal that of the highly photosynthetic, opportunistically growing, Ulva lactuca. This higher affinity may be due to a shorter diffusion path for $\mathrm{Ci}$ to the chloroplasts of the epidermal seagrass cells than to that of the mesophyll cells of the 2 macroalgae (Koch \& Beer unpubl. obs.), which could be beneficial under these intermediate $\mathrm{CO}_{2} / \mathrm{HCO}_{3}^{-}$ conditions. Assuming that mainly $\mathrm{CO}_{2}$ was utilised also at $\mathrm{pH} 7.0$, saturation for this substrate would occur at 
ca $0.09 \mathrm{mM}$ (at $1 \mathrm{mM}$ total $\mathrm{Ci}$ ), corresponding to an aerial $\mathrm{CO}_{2}$ concentration 7 times that of today. Both this and the 8 times higher $\mathrm{CO}_{2}$ concentration which would saturate seagrass photosynthesis (at $\mathrm{pH} \mathrm{6.0)}$ are in agreement with the paleo-oceanographic data of atmospheric $\mathrm{CO}_{2}$ concentrations during the Cretaceous. In contrast today, given the comparably lower air equilibrium $\mathrm{CO}_{2}$ concentration of seawater and the higher $\mathrm{pH}$ (linked with a higher $\mathrm{HCO}_{3}{ }^{-}$level), there is a clear disadvantage to the seagrasses; they are only ca half-saturated with regard to $\mathrm{Ci}$ while 1 of the macroalgae is $80 \%$ saturated and the other 2 are fully (Fig. 2a) or almost fully (Fig. 1) saturated.

While this research has omitted other potentially limiting factors for growth of marine macroalgae and seagrasses (including temperature effects on metabolic rates), it has been our contention that steady-state photosynthetic rates well represent the potential for productivity of submerged macrophytes (Lipkin et al. 1986) (Since the partitioning of photosynthate was not considered for the different morphological forms studied here, we have favoured the use of relative photosynthetic rates for each species at close to ambient $\mathrm{Ci}$ levels as a measure of growth potential.) If so, then the above relationships between the 2 marine macrophyte groups may also point out possible trends for the future in that seagrasses may regain higher photosynthetic yields and growth rates as future global atmospheric, and thus the in near-shore seawater dissolved, $\mathrm{CO}_{2}$ concentrations increase. On the other hand, as most marine macroalgae are already $\mathrm{Ci}$ saturated, no such change is expected for this plant group. Since the global $\mathrm{CO}_{2}$ level is predicted to double within the next ca $50 \mathrm{yr}$, and assuming that the seawater pH stays stable (but it will probably decrease some; Wetzel \& Grace 1983), it may be predicted from Fig. 2a that seagrasses will be able to nearly saturate their photosynthetic systems. However, it is also possible that ongoing eutrophication might counteract this advantage since those algae that are already Ci saturated could then utilise other nutrients (such as nitrogen and phosphorus) directly from the seawater (as they have no roots) and thus increase their growth potential. In places where both types of organisms grow together (e.g where Zostera marina and Ulva lactuca or Thalassia testudinum and Caulerpa spp. coexist, or where the seagrasses are epiphytised) the drifting or epiphytic algae could both shade out the seagrasses and/or contribute to increased organic loads of the sediment to such an extent that the formation of reducing compounds (e.g. sulphide) could poison the seagrass roots (Carlson et al. 1994). Thus, while it is concluded in this paper that the deficient $\mathrm{Ci}$ acquisition system of seagrasses may be partly responsible for diminishing seagrass beds today, it may depend on future successful management of eutrophication whether these plants will continue to inhabit (or re-inhabit) future, more $\mathrm{CO}_{2}$-rich, waters.

Acknowledgements. We thank Drs A. Eshel and Y Lipkin for their valuable criticism. Thanks also to Dr W. Henley and 2 other reviewers for their constructive remarks. S.B. thanks Dr R. Cooper for sponsoring a sabbatical at the Marine Sciences \& Technology Center, University of Connecticut, where this study was done.

\section{LITERATURE CITED}

Arthur MA, Hinga KR, Pilson MEQ, Whitaker E, Allard D (1991) Estimates of $\mathrm{pCO}_{2}$ for the last $120 \mathrm{My}$ based on $\delta^{13} \mathrm{C}$ of marine phytoplankton organic matter. EOS 72:166

Axelsson L, Ryberg H, Beer S (1995) Two modes of bicarbonate acquisition in Ulva lactuca. Plant Cell Environ 18: $439-445$

Beer S (1989) Photosynthesis and photorespiration in marine angiosperms. Aquat Bot 34:153-166

Beer S (1994) Mechanisms of inorganic carbon acquisition in marine macroalgae (with special reference to the Chlorophyta). Prog Phycol Res 10:179-207

Beer S, Bjork M (1994) Photosynthetic properties of protoplasts, as compared with thalli, of Ulva fasciata (Chlorophyta). J Phycol 30:633-637

Beer S, Eshel A (1983) Photosynthesis of Ulva sp. Il utlization of $\mathrm{CO}_{2}$ and $\mathrm{HCO}_{4}$ ' when submerged. J Exp Mar Biol Ecol 70:91-97

Beer S, Eshel A, Waisel, Y (1980) Carbon metabolism in seagrasses III activities of carbon fixing enzymes in relation to internal salt concentrations. J Exp Bot 31:1027-1033

Berner RA (1991) A model for atmospheric $\mathrm{CO}_{2}$ over phanerozoic tıme. Am J Sci 291:339-376

Berner RA, Lasaga A, Garrels RM (1983) The carbonate-silicate geochemical cycle and its effect on atmospheric $\mathrm{CO}_{2}$ over the past 100 million years. Am J Sci 283:641-683

Carlson PR, Yarbro L, Barber TR (1994) Relationship of sediment sulfide to mortality of Thalassia testudinum in Florida Bay. Bull Mar Sci 54:733-746

den Hartog C (1970) The seagrasses of the world. North Holland Publ Co, Amsterdam

Dennison WC, Orth RJ, Moore KA, Stevenson JC, Carter V, Kollar S, Bergstrom PW, Batiuk RA (1993) Assessing water quality with submerged aquatic vegetation. Bioscience 43:86-94

Drechsler Z, Sharkia R, Cabantchık Zl, Beer S (1993) Bicarbonate uptake in the marine macroalga Ulva sp. is unhibted by classical probes of anion exchange by red blood cells. Planta 191:34-40

Drechsler Z. Sharkia R, Cabantchik ZI, Beer S (1994) The relationship of arginine groups to photosynthetic $\mathrm{HCO}_{3}$ uptake in Ulva sp. mediated by a putative anion exchanger. Planta 194:250-255

Inskeep WP, Bloom PR (1985) Extinction coefficients of chlorophyll $a$ and $b$ in N,N-dimethylformamide and $80 \%$ acetone. Plant Physiol 77:483-485

Jagels R (1983) Further evidence for osmoregulation in epidermal leaf cells of seagrasses. Am J Bot 70:327-333

Kubler JE, Raven JA (1994) Consequences of light limitation for carbon acquisition in three rhodophytes. Mar Ecol Prog Ser 110:203-209

Lipkin Y, Beer S, Best EPH, Kairesalo T, Salonen K (1986) Primary production of macrophytes: terminology, approaches 
and a comparison of methods. Aquat Bot 26:129-142

McRoy CP, McMillan C (1977) Production ecology and physiology of seagrasses. In: McRoy CP, Helferrich C (eds) Production ecology and physiology of seagrasses. M Dekker, New York, p 58-87

Smith RD, Dennison WC, Alberte RS (1984) Role of seagrass photosynthesis in root aerobic processes. Plant Physiol 74 1055-1058

Spivack AJ, You CF, Smith HJ (1993) Foraminiferal boron isotope ratios as a proxy for surface ocean $\mathrm{pH}$ over the past 21 My. Nature 363:149-151

This article was submitted to the editor
Thom RM (1995) $\mathrm{CO}_{2}$-enrichment effects on eelgrass (Zostera marina L.) and bull kelp (Nereocystis leutkeana (Mert.) P\&R). Water Air Soil Pollut 82:1-9

Tomlinson PB (1980) Leaf morphology and anatomy in seagrasses. In: Phillips RC. McRoy CP (eds) Handbook of seagrass biology: an ecosystems perspective. Garland, New York, p 7-28

Wetzel RG, Grace JB (1983) Aquatic plant communities. In: Lemon ER (ed) $\mathrm{CO}_{2}$ and plants: the response of plants to rising levels of atmospheric carbon dioxide. Westview Press, Boulder, p 223-280

Manuscript first received: April 18, 1996

Revised version accepted: June 25, 1996 